the Society of Chemical Industry. He served on the Council of the Chemical Society and was a manager of the Royal Institution. He always had at heart the welfare of Queen Mary College, its students and its old students. $\mathrm{He}$ was one of a small band of distinguished old students who met together several times a year to keep track of old members of the College and to give them a helping hand when necessary., He was made a fellow of Queen Mary College in 1937.

Fox was always willing to help : he never allowed red-tape to interfere with his official contacts with industry. He gladly saw the representatives of chemical manufacturers and other traders, and freely gave his knowledge and experience to help them to overcome those difficulties inseparable from governmental control. Although his whole life was devoted to the service of chemistry, he yet found time to act as treasurer of his church for many years. He was kind and generous to his colleagues and lost no opportunity of encouraging those young members of his staff who showed a lively interest in chemistry. His enthusiasm for chemistry remained to the end, when he could still be seen moving from room to room of the Laboratory - asking, suggesting, encouraging.

His services were rewarded by the honour of the O.B.E. in 1920, of the C.B. in 1938 and of a knighthood in 1944 ; his services to chemistry were acknowledged by the Royal Society in 1943, when he was elected a fellow. He leaves a widow, a son and a daughter.

A. G. Francis.

\section{Sir Percy Nunn}

That so distinguished a career as that of Sir Percy Nunn should have terminated in a sort of banishment from his native land, and therefore from the scenes and causes to which he had devoted his eminent gifts, must indeed be accounted a tragedy. So long as he was able to spend a few summer months in England, after many months of exile to Madeira for reasons of health, his lot seemed tolerable. But the grim course of world events meant for him complete exile, a condition which, however, his nobility of character enabled him to bear with exemplary patience and fortitude. He died on December 12 at the age of seventy-four.

That Nunn was first of all, at least in the chronological sense, a man of science, is shown by his first substantial piece of writing, his "Aims of Scientific Method", and by his subsequent work on the nature and teaching of mathematics. It is scarcely too much to say, however, that even then, and still more decidedly later on, when he became an active member of the Aristotelian Society, he was essentially a philosophic thinker. The broad philosophic outlook characterized all his literary work. He wrote a book bearing the modest and not uncommon title "Exercises in Algebra". The book must have been a sore puzzle to teachers who had not got far from the 'Hall-and-Knight' tradition. It was, in fact, the result of years of teaching combined with reflexion, and finally of many months of patient and laborious research in the British Museum and elsewhere. It could not be a best-seller in the secondary schools, but it could, and it did, help towards a reorganization of school mathematics.

At a later stage in Nunn's career, he published his well-known "Education: its Data and First Principles", a work which summed up in brief compass the substance of his courses of lectures on the subject.
That book, published two years after the end of the first world war, was, for one thing, a marvel of prophecy as to the shape of things to come. The author's main purpose was "to re-assert the claim of Individuality to be regarded as the supreme educational ideal, and to protect that ideal against both the misprision of its critics and the incautious advocacy of its friends". The book, remarkable both for its clear vision and its massive learning, still stands as the finest systematic defence of the only educational ideal which can make the world safe for democracy.

Some of Nunn's old friends will remember how, as vice-principal of the new London Day Training College, he was introduced to them nearly forty years ago, by the principal, the late Sir John Adams, in a rather dingy little room near Holborn which formed the temporary headquarters of the College. These were the roots, the fruits of which are seen to-day in the great University Institute of Education. That development was mostly due to the creative genius of one man, and that man was Percy Nunn. No longer is it necessary that teachers in the British Commonwealth of Nations should go to the United States if they wish to pursue advanced studies in education. They can now get what they want in England, thanks to the efforts of Sir Percy Nunn, and to those of his singularly appropriate successor, Sir Fred Clarke.

As the advocate of a cause, Nunn was a persuasively quiet and eloquent speaker. There was a marvellous flow of language, but every word told. He was a true and loyal friend and a delightful companion, and in his exile he liked to recall in his letters the days of small things in a distant past. T. RAYMONT.

\section{Mr. J. Edmund Clark}

James Nidmund Crark died on December 16 at the age of ninety-four. He was the last of the fourteen children of James and Eleanor Stephens Clark. His father died at the age of ninety-four, and the average age of his nine brothers and sisters who reached maturity was more than eighty-two when they died. His mother was one of a family of seventeen children.

Clark was educated at Bootham School, York, at University College, London, and at the University of Heidelberg. He returned to the famous Quaker school for boys at York as junior master during 1869-72, and after further training, he succeeded his life-long friend, later Prof. Silvanus P. Thompson, as science master at Bootham in 1875. After twentytwo years as a schoolmaster, he gave it up, largely because of deafness, and went to London in 1897, where he began a new career as export merchant. $\mathrm{He}$ retired in 1929.

Keenly concerned as Clark was for every branch of natural science, it was meteorology and phenology which particularly claimed his interest. For twentyfive years he was secretary of the Phenological Committee of the Royal Meteorological Society, and was for long a member of the Society's Council. High tribute was paid, when he retired in 1936, to his services to phenological studies on the effect of climatic conditions on natural phenomena.

In 1879 Clark married Lucretia H. Kendall, of Boston, Mass. She died in 1937, as did also their only son, Roderic. Throughout his life, Clark was a devoted and active member of the Society of Friends in York, Croydon, Purley and Street. 